\title{
Mortality among children and young persons in Sweden in relation to childhood socioeconomic group
}

\author{
DENNY VÅGERÖ ${ }^{1}{ }^{2}$ AND VIVECA ÖSTBERG ${ }^{1}$ \\ From ${ }^{1}$ Department of Epidemiology, Institute of Environmental Medicine, Karolinska Institute, Stockholm; and \\ ${ }^{2}$ Swedish Institute of Social Research, Stockholm, Sweden.
}

\begin{abstract}
More than 1.5 million children in Sweden were followed up for the period 1961-1979 with respect to mortality. Mortality differences by socioeconomic group were studied for the age groups 1-19 years. Children in families of non-manual workers, both boys and girls, had a significantly lower mortality than children of manual workers and children of self employed persons. The socioeconomic differences in risk of dying were greater among boys than among girls. For boys, the socioeconomic differences grew smaller as the boys grew older.
\end{abstract}

Health inequalities have recently come to be looked upon as a major target for health policy, for instance by the WHO in their HFA2000 campaign. ${ }^{1}$ This development has in part been influenced by research providing evidence on health inequalities in various countries. ${ }^{2}$ The Black report presented evidence from Britain, but also suggested that health inequalities in Sweden may have already been eradicated. ${ }^{3}$ The reference was to infant mortality, but later evidence suggests that in Sweden both birth weight and risk of dying during the first 12 months are indeed linked to the socioeconomic position of the family and in particular of the mother. ${ }^{45}$

While adult mortality by social class in Sweden has been described to some extent ${ }^{6}$ there has been no analysis of mortality by social class for children or young people. The very young are those most vulnerable and dependent on their environment and on parental care. It is possible that this is the explanation for the largest gap by social class being among the very young. British mortality statistics suggest that the relative risk of dying for a lower class as compared to an upper class child is greater before age 1 year than at any other time in life. ${ }^{7}$ Between 1 and 4 years it is still large and after that period it is usually assumed that the health gap, although persisting, diminishes through adulthood and into old age. ${ }^{8}$ West, analysing in greater detail the age specific social class differences in mortality, concluded, however, that there is no linear relation between class related risk of dying and age. Instead he suggested there is a tendency for class differences in mortality to disappear in late adolescence, only to be reintroduced at a later point in life, ie, in the age groups after 20 years. Disregarding this fact, he argued, would bias our understanding of how these differences came about in the first place. ${ }^{9}$ It could be added here that the theoretical explanations for health inequality, notably for mortality differences by class, are heavily dependent on the same set of British sources (the OPCS mortality statistics) and hence, underlying the theoretical arguments, there is already an "England and Wales bias".

For these reasons it was thought that a study on child mortality by socioeconomic group in Sweden would be of general interest. Its purpose is both to give evidence on health inequalities in Sweden and to test the hypothesis that class differences in mortality tend to diminish during childhood.

\section{Methods}

POPULATION UNDER STUDY

The study population was defined as all those who were born between 1946 and 1960 and who were enumerated in the 1960 population census. Thus 809150 boys and 769309 girls were included. This group was followed up for the period 1961-1979. All deaths that occurred during this period and for which the age at death was in the age range from 1 to 19 years, were included. There were 5582 such deaths among boys and 3015 among girls. The age distribution of these deaths and the corresponding person years at risk distribution can be seen in table 1 .

The study used a new epidemiological tool, the so called Census linked Deaths Registry (CDR), that links the 1960 population census to the National Cause of Death Registry for the 1961-79 period. The 
Table 1 Number of deaths and person years at risk by gender and age

\begin{tabular}{|c|c|c|c|c|c|c|}
\hline \multirow[b]{2}{*}{ Age group (years) } & \multicolumn{3}{|c|}{ Number of deaths } & \multicolumn{3}{|c|}{ Number of person years at risk } \\
\hline & Boys & Girls & All & Boys & Girls & All \\
\hline $\begin{array}{c}1-4 \\
5-9 \\
10-14 \\
15-19\end{array}$ & \begin{tabular}{r|}
408 \\
848 \\
1065 \\
3261
\end{tabular} & $\begin{array}{r}287 \\
553 \\
717 \\
1458\end{array}$ & $\begin{array}{r}695 \\
1401 \\
1782 \\
4719\end{array}$ & $\begin{array}{r}472751 \\
1771407 \\
3149597 \\
4045750\end{array}$ & $\begin{array}{r}447488 \\
1673480 \\
2981229 \\
3846545\end{array}$ & $\begin{array}{r}920239 \\
3444887 \\
6130826 \\
7892295\end{array}$ \\
\hline All ages & 5582 & 3015 & 8597 & 9439505 & 8948742 & 18388247 \\
\hline
\end{tabular}

linkage was made as a computerised record linkage, using the unique 10 digit personal identification number used in Sweden for both medical and census purposes. The loss of individuals in matching of identification codes has been estimated to be less than $1 \%$. Fuller descriptions of this registry are available. 61011

The boys and girls included in the study were below the age of 15 at the time of the census. Provided that they were not already working, the census gives details about the "occupational status" of the head of the household, usually the father. This information has been used to define three socioeconomic groups, here defined as children from families of self employed persons, of non-manual workers and of manual workers. They comprised $22 \cdot 8 \%, 28.5 \%$ and $48.7 \%$ of the whole study population. The group of self employed persons was less homogeneous than the other two and also included children of persons classified as supervisors. Because of the limited information on socioeconomic factors for children, a more sophisticated classification was not possible.

\section{METHODS OF ANALYSIS}

For each socioeconomic group as described above the death rate was calculated for the age groups 1-4, 5-9, $10-14,15-19$ and separately for boys and girls. There is also an overall death rate for each group, obtained as a weighted average of age specific rates. Weights are proportional to the size of each age group at the midpoint of the study period. ${ }^{12}$ The age at death was calculated as year of death minus year of birth. The corresponding denominators were received from a person year at risk matrix. This was constructed by adding a year to each 1 year age group as a person in the study went through that age.

Since the overall mortality in this population of children is very low (61 for boys and 39 for girls per 100000 years) it would not make any difference whether we reduced the person year matrix with those dying during the study period or not. The person year distribution in table 1 is thus a very near approximation.

To compare the death rates of the three socioeconomic groups directly, relative risks were also calculated. The children in families of non-manual workers were then taken as the reference group. Relative risks were calculated as the ratio between the death rate in one of the other two groups and the death rate for the reference group. Approximate 95\% confidence limits were also calculated, using a method suggested by Rothman. ${ }^{13}$

Children of manual workers and children of nonmanual workers were compared and analysed in more detail. Age specific relative risks were calculated by 1 year age groups. These relative risks were plotted against age from 1 to 19 years and a regression line was fitted for boys and girls respectively, to test the hypotheses that there is a tendency for socioeconomic mortality differences to diminish towards late adolescence.

Nine causes of deaths were thought to be of special interest or to be sufficiently common for further analysis. They were the following diagnoses, referred to by their ICD code (7th revision):-infective and parasitic diseases (ICD code 001-138); neoplasms, excluding leukaemia (140-203, 205-239); leukaemia (204); diseases of the nervous system and sense organs (330-398); diseases of the circulatory system (400468); diseases of the respiratory system (470-527); diseases of the digestive system (530-587); congenital malformations (750-759); accidents, poisonings and violence (800-999). For these, death rates were calculated. The total mortality reduced by deaths from accidents, poisonings and violence was also analysed in the same way. All analyses of cause specific mortality excluded deaths during 1969 and 1970, because there was a change in the international classification of diseases from 1969 and it is believed that the coding of diagnoses during the following 2 years was less reliable than later.

\section{Results}

Table 2 shows the total mortality by socioeconomic group for boys and girls. It can be seen that boys had a higher mortality than girls in each socioeconomic group, in each age group and in each combination of 
Table 2 Total mortality among children (deaths per 100000 person years at risk), relative risks (RR) and 95\% confidence limits (95\% CL) by gender, age and socioeconomic group. Sweden 1961-79.

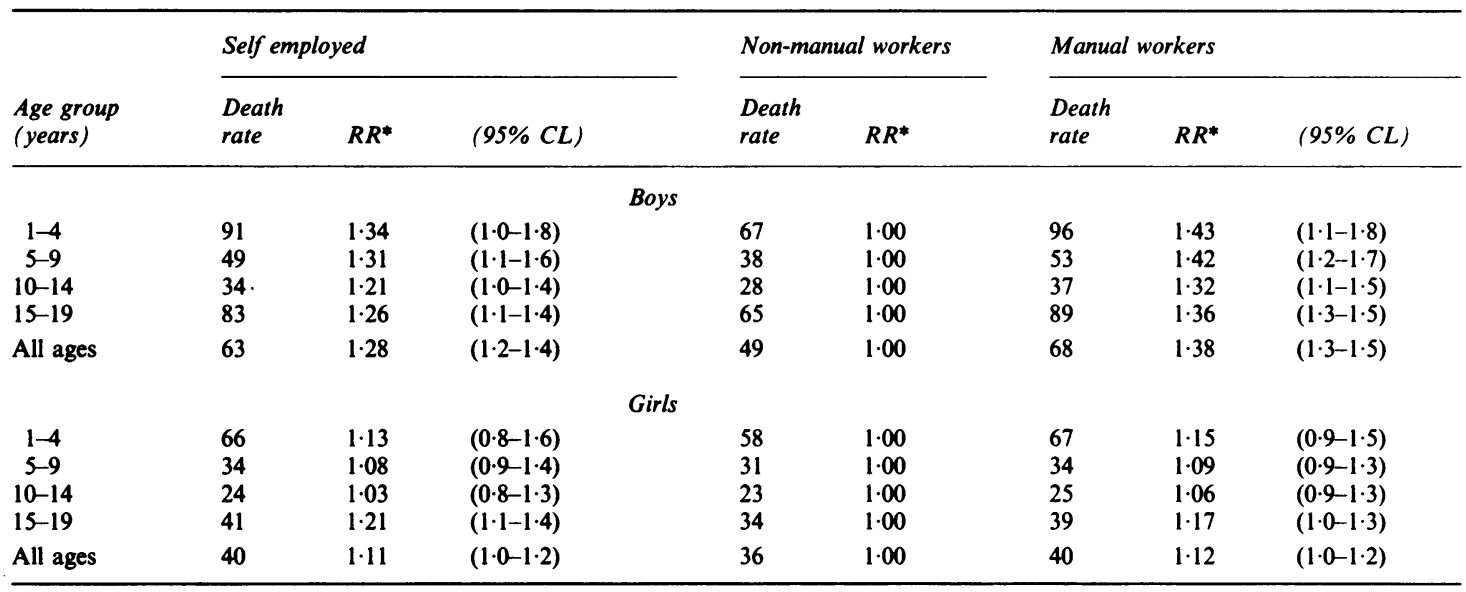

* non-manual workers are the reference group $(R R=1)$

Table 3 Cause specific mortality for 10 groups of causes (deaths per 100000 person years at risk) by gender and socioeconomic group. Children aged 1-19 years, Sweden 1961-79.

\begin{tabular}{|c|c|c|c|c|}
\hline Cause of death (ICD number) & Gender & $\begin{array}{l}\text { Self } \\
\text { employed }\end{array}$ & $\begin{array}{l}\text { Non-manual } \\
\text { workers }\end{array}$ & $\begin{array}{l}\text { Manual } \\
\text { workers }\end{array}$ \\
\hline $\begin{array}{l}\text { Infective and parasitic diseases } \\
(001-138)\end{array}$ & $\begin{array}{l}\text { Boys } \\
\text { Girls }\end{array}$ & $\begin{array}{l}1 \cdot 1 \\
1 \cdot 0\end{array}$ & $\begin{array}{l}1 \cdot 3 \\
1 \cdot 5\end{array}$ & $\begin{array}{l}2 \cdot 0 \\
1 \cdot 4\end{array}$ \\
\hline $\begin{array}{l}\text { Neoplasms (leukaemia excluded) } \\
(140-203,205-239)\end{array}$ & $\begin{array}{l}\text { Boys } \\
\text { Girls }\end{array}$ & $\begin{array}{l}5 \cdot 2 \\
4 \cdot 3\end{array}$ & $\begin{array}{l}4 \cdot 5 \\
4 \cdot 2\end{array}$ & $\begin{array}{l}5 \cdot 8 \\
4 \cdot 1\end{array}$ \\
\hline $\begin{array}{l}\text { Leukaemia } \\
\text { (204) }\end{array}$ & $\begin{array}{l}\text { Boys } \\
\text { Girls }\end{array}$ & $\begin{array}{l}3 \cdot 7 \\
4 \cdot 9\end{array}$ & $\begin{array}{l}3 \cdot 7 \\
4 \cdot 6\end{array}$ & $\begin{array}{l}4 \cdot 0 \\
2 \cdot 7\end{array}$ \\
\hline $\begin{array}{l}\text { Diseases of the nervous system and sense organs } \\
(330-398)\end{array}$ & $\begin{array}{l}\text { Boys } \\
\text { Girls }\end{array}$ & $\begin{array}{l}3 \cdot 0 \\
3 \cdot 0\end{array}$ & $\begin{array}{l}3 \cdot 6 \\
2 \cdot 9\end{array}$ & $\begin{array}{l}3 \cdot 2 \\
2 \cdot 4\end{array}$ \\
\hline $\begin{array}{l}\text { Diseases of the circulatory system } \\
(400-468)\end{array}$ & $\begin{array}{l}\text { Boys } \\
\text { Girls }\end{array}$ & $\begin{array}{l}1 \cdot 2 \\
1 \cdot 1\end{array}$ & $\begin{array}{l}0.8 \\
0.9\end{array}$ & $\begin{array}{l}1 \cdot 1 \\
1 \cdot 2\end{array}$ \\
\hline $\begin{array}{l}\text { Diseases of the respiratory system } \\
(470-527)\end{array}$ & $\begin{array}{l}\text { Boys } \\
\text { Girls }\end{array}$ & $\begin{array}{l}3 \cdot 5 \\
2 \cdot 3\end{array}$ & $\begin{array}{l}3 \cdot 1 \\
2 \cdot 6\end{array}$ & $\begin{array}{l}4 \cdot 1^{*} \\
3 \cdot 8\end{array}$ \\
\hline $\begin{array}{l}\text { Diseases of the digestive system } \\
(530-587)\end{array}$ & $\begin{array}{l}\text { Boys } \\
\text { Girls }\end{array}$ & $\begin{array}{l}2 \cdot 3 \\
1 \cdot 3\end{array}$ & $\begin{array}{l}1 \cdot 8 \\
1 \cdot 7\end{array}$ & $\begin{array}{l}2 \cdot 0 \\
1.6\end{array}$ \\
\hline $\begin{array}{l}\text { Congenital malformations } \\
(750-759)\end{array}$ & $\begin{array}{l}\text { Boys } \\
\text { Girls }\end{array}$ & $\begin{array}{l}4 \cdot 3 \\
3.9\end{array}$ & $\begin{array}{l}3 \cdot 5 \\
3 \cdot 8\end{array}$ & $\begin{array}{l}5 \cdot 4^{*} \\
3 \cdot 3\end{array}$ \\
\hline $\begin{array}{l}\text { Accidents, poisonings and violence } \\
(800-999)\end{array}$ & $\begin{array}{l}\text { Boys } \\
\text { Girls }\end{array}$ & $\begin{array}{l}34 \cdot 6^{*} \\
14 \cdot 5^{*}\end{array}$ & $\begin{array}{l}24 \cdot 6 \\
11 \cdot 5\end{array}$ & $\begin{array}{l}37 \cdot 2^{*} \\
16 \cdot 7^{*}\end{array}$ \\
\hline All causes except accidents etc & $\begin{array}{l}\text { Boys } \\
\text { Girls }\end{array}$ & $\begin{array}{l}28 \cdot 3 \\
25 \cdot 7\end{array}$ & $\begin{array}{l}24 \cdot 7 \\
24 \cdot 1\end{array}$ & $\begin{array}{l}30 \cdot 8^{*} \\
23 \cdot 8\end{array}$ \\
\hline
\end{tabular}

* significantly different from the reference group (non-manual families) $p<0.05$ (two tailed test). 
the two. It is also true that in each age group, in both genders and in all combinations of these, children in families of non-manual workers had a lower mortality than both those of self-employed persons and those of manual workers. These latter two groups had a more similar total mortality, although for boys it was always slightly higher for children of manual workers.

Table 3 gives cause specific death rates and relative risks for nine groups of ICD codes. The most clear difference is for deaths from accidents, poisonings and violence. From this cause of death, children in families of manual workers had a $51 \%$ (boys) and $45 \%$ (girls) excess death rate, when compared to children of non-manual workers. For children in families of self employed persons, that excess risk was $41 \%$ (boys) and $26 \%$ (girls).

For respiratory disease there was a similar pattern, with an excess risk of $32 \%$ (boys) and $46 \%$ (girls) in families of manual workers. Among boys, the risk of dying from cancer or congenital malformations was greatest in families of manual workers but this was not the case for girls. For circulatory disease again, the boys and girls in families of non-manual workers had a lower mortality than both other groups. Excluding the deaths from accidents and violent causes reduced the socioeconomic group differences in mortality somewhat (table 3). The manual/non-manual group difference persisted among boys, but disappeared among girls.

Comparing all cause mortality for children of manual and non-manual workers directly for each age (1 year age groups) from 1 to 19 years of age produced the results shown in figs 1 (boys) and 2 (girls). The relative risks are plotted as 19 points and a regression line is fitted. Taking the position of the regression line as the best risk estimate at a particular age gives a near

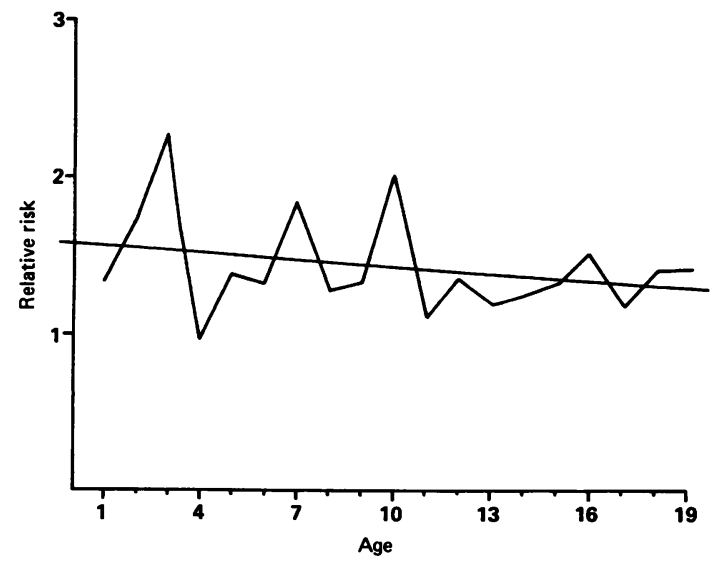

Fig 1 Relative risks for boys (manual workers/non-manual workers) by age

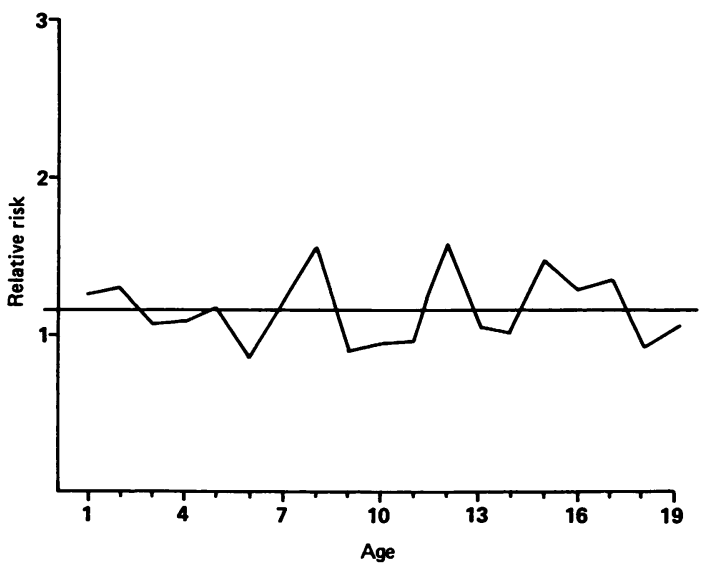

Fig 2 Relative risks for girls (manual workers/non-manual workers) by age

$60 \%$ excess risk for male children of manual workers at the age of 1 year and a near $30 \%$ excess risk at the age of 19 years. For girls there was a $15 \%$ excess risk at all ages.

An attempt to compare Swedish class differences in children with the corresponding differences in Britain for the same period was made. For this purpose we calculated the observed and expected deaths in the age groups 1-14 years for the combined classes I, II and IIIN and for the combined classes IIIM, IV and V, by using the 1970-72 OPCS statistics, ${ }^{14}$ which should be the best approximation to the 1961-79 study period for the Swedish data. The lower classes could thus be estimated to have an excess risk of about $30 \%$ for boys and about $20 \%$ for girls. The equivalent for Sweden is perhaps to combine the self employed and nonmanual groups and compare these with the manual group. Using the death rates in table 2, this comparison resulted in somewhat smaller class differences for Sweden, estimated to be around $25 \%$ for boys and $10 \%$ for girls in the same age span (1-14 years).

\section{Discussion}

There is a clear and significantly lower risk of dying for children from non-manual families as compared to those of manual workers and self employed persons, both for boys and for girls. This applies to every age group for boys. The relative risks are higher for boys than for girls. The general tendency for socioeconomic mortality differences to diminish with age in the age span 1-19 years is clear for boys (fig 1), for whom the relative risk is 1.6 at the age of 1 year, decreasing to 1.3 at the age of 19. For girls, however, no such tendency could be demonstrated (fig 2 ). 
Excluding accidents reduced the class differential but did not eliminate it. The tendency among boys for class differentials to diminish with age (up to 19 years) was also still present when excluding deaths from accidents, poisonings and violence. However, in the age group 15-19 years that difference was in fact less than $10 \%$.

For girls there is a smaller relative risk for manual as compared to the non-manual class in general; there is also no evidence that age modifies that relative risk.

In conclusion, there would seem to be some class differences in Sweden during the study period in the risk of dying at a young age, especially for boys. The size of these differences may be smaller than the corresponding class differences in Britain for the same period. However, even a relatively small excess risk corresponds to a large number of deaths. From the death rates calculated in this study we estimate the proportion of deaths attributable to a child's socioeconomic group to be $20 \%$ among boys and $8 \%$ among girls. Thus, if mortality among children and young persons in general could be reduced to that of children in families of non-manual workers an estimated 150 deaths out of 1000 deaths occurring each year in Sweden could be prevented.

Address for correspondence and reprints: Dr Denny Vågerö, Department of Epidemiology, Institute of Environmental Medicine, Karolinska Institute, Box 60208, S-104 01 Stockholm, Sweden.

\section{References}

${ }^{1}$ World Health Organisation. Targets for health for all. Targets in support of the European regional strategy for health for all. Copenhagen: World Health Organisation Regional Office for Europe, 1986.
2 Illsley R, Svensson PG, eds. The health burden of social inequities. Country profiles from 20 member states of the European region of the World Health Organisation. Copenhagen: World Health Organisation Regional Office for Europe, 1986.

${ }^{3}$ Department of Health and Social Security. Inequalities in health. Report of a research working group. London: DHSS, 1980.

${ }^{4}$ Ericson A, Ericsson M, Westerholm P, Zetterström R. Pregnancy outcome and social indicators in Sweden. Acta Paediatr Scand 1984; 73: 69-74.

${ }^{5}$ Zetterström R, Ericsson M. Hälsa och social klass. Spädbarnsdödlighet och graviditetsutfall (Health and social class. Infant mortality and pregnancy outcome). Socialmedicinsk Tidskrift 1987: 64: 33-6.

${ }^{6}$ Vågerö D, Norell S. Social class and mortality in Sweden. Exploring a new epidemiological tool. Scand J Soc Med 1989; 17: 49-58.

${ }^{7}$ Office of Population Censuses and Surveys. Registrar General's decennial supplement on occupational mortality 1970-72. London: HM Stationery Office, 1978.

${ }^{8}$ Hart N. Inequalities in health: The individual versus the environment. $J R$ Statist Soc 1986; 149: 228-46.

${ }^{9}$ West P. Inequalities? Social class differentials in health in British youth. Soc Sci Med 1988; 27: 291-6.

${ }^{10}$ Statistiska Centralbyrån. Dödsfallsregistret 1961-70. Promemorior frän SCB 1981:2 (Memos on the censuslinked Deaths Registry). Stockholm: Statistics, Sweden, 1982.

${ }^{11}$ Statistiska Centralbyrån och Bostadsstyrelsen. Redogörelse för folk- och bostadsräkningens uppläggning och utförande. (An account of the 1960 Population Census). Stockholm: Statistics, Sweden, 1965.

12 Statistiska Centralbyrån. Statistisk årsbok 1971. (Statistical Abstract of Sweden 1971). Stockholm: Statistics, Sweden, 1971.

13 Rothman KJ, Boice I. Epidemiologic analysis with a programmable calculator. Boston: Epidemiology Res Inc,

14 Office of Population Censuses and Surveys. Registrar $\stackrel{1982 .}{=}$ General's decennial supplement on occupational mortality 1970-72. London: HM Stationery Office, 1978: 217.

Accepted for publication March 1989 